\title{
PERKEMBANGAN TANAH DARI BAHAN VULKAN PADA TOPOSEKUEN WILAYAH BANGLI SELATAN, KABUPATEN BANGLI
}

\author{
Nuranita Naningsi \\ Program studi Teknik Industri, Fakultas Teknik, Universitas Mahendradatta \\ Jl.Ken Arok No.12, Peguyangan, Denpasar, Bali 80115 \\ *Email: nuranitananingsi@yahoo.co.id
}

\begin{abstract}
Abstrak - $\quad$ Penelitian "Perkembangan Tanah dari Bahan Vulkan pada Toposekuen wilayah Bangli Bagian Selatan" ini bertujuan untuk mengetahui : (1) Mengkaji proses pembentukan dan perkembangan tanah yang terbentuk dari bahan vulkan pada banjar topografi diwiayah Bangli selatan, Kabupten Bangli, (2) Memperoleh data karakteristik tanah diwilayah Bangli Selatan Kabupaten Bangli, (3) Mengetahui potensi lahan untuk pengelolaan pertanian di wilayah Bangli Selatan, Kabupaten Bangli.

Penelitian ini dilaksanakan dengan metode survai tanah, analisis Laboratorium, dan ditunjang dengan data-data sekunder. Tiga profil yang mewakili Banjar Topografi dipilih berdasarkan ketinggian tempat yang berbeda, profil ( $\mathrm{N}-1)$ dengan ketinggian tempat $850 \mathrm{~m}$ dpl, profil $(\mathrm{N}-2)$ ketinggian tempat $540 \mathrm{~m}$ dpl, dan profil ( $\mathrm{N}$-1) ketinggian tempat $200 \mathrm{~m}$ dpl. Ketiga profil ini mempunyai kiblat lereng yang sama yaitu kiblat lereng selatan.

Bahan induk yang terbentuk di daerah penelitian berasal dari bahan vulkanik, yaitu tufa vulkan dan endapan lahar dari Buyan, Beratan, dan Batur Purba. Daerah penelitian termasuk dalam tipe iklim A (sangat basah). Proses genesis tanah yang terjadi didaerah penelitian adalah untuk lereng atas mengalami proses erosi, lereng tengah mengalami proses transportasi, dan lereng bawah mengalami proses deposisi.

Ketiga profil pewakil telah mengalami proses horisonisai. Tingkat perkembangan tanah berada pada tahap virile. Karakteristik tanah agak masam, kapasitas tukar kation rendah sampai sedang, kejenuhan basa rendah sampai sedang, bahan organik sangat rendah sampai rendah, tekstur pasir berlempung sampai lempung. Jenis mineral yang terdapat pada ketiga profil didominasi oleh mineral haloisit.

Berdasarkan hasil penelitian mempengaruhi sifat-sifat tanah yang terbentuk. Pada lereng atas terbentuk solum sangat dalam pada kedalaman $>177 \mathrm{~cm}$, lereng tengah terbentuk solum yang dalam pada kedalaman > $153 \mathrm{~cm}$ dan kaki lereng terbentuk solum yang dangkal pada kedalaman > $137 \mathrm{~cm}$. Wilayah Bangli Bagian Selatan berpotensi dalam mendukung pertumbuhan tanaman dan meningkatkan produksi pertanian.
\end{abstract}

Kata Kunci: Tuva vulkanik, Perkembangan Tanah, Bangli Selatan.

Abstract- Research on the development of soil from vulkan material in the toposcopic southern Bangli Region as for the purpose of the study is as follows: (1) the process of formation and development of soil formed from toposcopic volcanic material in the southern, Bangli Region (2) obtain data on soil characteristics in the southern Bangli Region (3) knowing the potential of land for agricultural management in the southern, Bangli Region.

This research was carried out with methods of soil survey, laboratory analysis, and supported with secondary data. Three profiles that represent Local Topography is selected based on the height of the different places, profile (N-1) with an altitude of 850 metres above sea level, profile (N-2) with an altitude of 540 metres above sea level, and the profile ( $N-1) h$ with an altitude of 200 metres above sea level. A third profile is have the same slope direction that is the direction the southern slope.

Parent material formed in the area of research is derived from volcanic material, namely tuff deposits of lava and Vulcan of Buyan and Beratan, Batur, Ancient. Research areas included in the climate type $A$ (very wet). The process of genesis of soils that occur in research is to the top slopes are experiencing a process of erosion, the middle slopes of the transport process and foot slopes of the deposition process.

Third that profile has undergone a process of horisonisasi. The level of development of land is at the stage of virile. The characteristics of the soil a bit sour, cation exchange capacity of low to medium, base saturation is low to moderate, organic material is very low to low, the texture of the sand very clay to clay. Types of minerals found in the third profile dominated by halloysite minerals. 
Based on the results of research affect soil properties that are formed. On the top slopes are formed very deep in the depths of the solum > 177 centi metres, middle slopes formed solum in depth $>153$ centi metres and foot slopes formed a shallow at a depth of solum > 137 centi metres. Bangli area Southern potentially in support of plant growth and increase agricultural production.

Keywords: Tuva volcanic, Land Development, South Bangli.

\section{Pendahuluan}

Faktor pembentuk tanah merupakan penentu dalam pembentukan jenis-jenis tanah yaitu: iklim, bahan induk, jasad hidup, topografi dan waktu. Kelima faktor tersebut mempengaruhi perkembangan tanah, sehingga kita mengerti mengapa tanah itu bervariasi dari satu tempat ketempat yang lain, faktor-faktor pembentuk tanah tersebut tidak bekerja sendiri-sendiri, tapi saling mempengaruhi dan bekerja sama menghasilkan sifat-sifat tanah dengan karakteristik tertentu (Darmawijaya, 1997).

Pada keadaan tertentu salah satu faktor dapat lebih menonjol dari faktor lainnya dalam mengontrol perkembangan tanah, adalah salah satu keadaan dimana topografi lebih mengontrol pembentuk tanah dibanding faktor pembentuk lain akan membentuk tanah deretan tanah atau toposekuen.

Didaerah pegunungan, lereng merupakan salah satu faktor yang menentukan perkembangan tanah. Lereng memegang peranan dalam proses erosi, transportasi, dan deposisi. Proses-proses tersebut akan berpengaruh terhadap sifat fisik dan morfologi tanah, demikian juga terhadap beberapa sifat kimia tanah. Faktor kemiringan, posisi, dan bentuk lereng berpengaruh dalam proses pelapukan, pencucian dan perkembangan tanah (Djenudin, 1979).

Bahan induk tuva vulkanik yang juga merupakan sebagian dari bahan vulkan, pada daerah beriklim udik akan lebih cepat melapuk membentuk mineral jenis alovan yang merupakan aluminium silikat almorf dan membentuk kompleks dengan bahan organik tanah. Tanah yang kaya akan alovan merupakan tanah yang mempunyai sifat andik.

Tanah diwilayah ini terbentuk dari bahan induk tuva vulknik dengan topografi datar sampai berbukit. Topgrafi dan variasi lereng sebagai unsur dan bentang lahan (landscope) sering merupakan faktor yang menentukan dalam perkembangan tanah.

Bertitik tolak dari hal tersebut dilakukan penelitian tentang perkembangan tanah yang terbentuk dari bahan vulkan pada toposekuen diwilayah bangli bagian selatan.

\section{Metode Penelitian}

\subsection{Lokasi Dan Waktu}

Daerah penelitian terletak antara $8^{0}$ 8'30"sampai $8^{0} 3187^{\prime \prime}$ Lintang Selatan dan antara $115^{\circ} 13^{\prime} 48^{\prime \prime}$ sampai $115^{\circ} 2724$ " bujur timur. Desa Pengotan berada pada ketinggian $1050 \mathrm{~m}$ dpl, Desa Kubu dengan ketinggian $540 \mathrm{~m}$ dpl dan desa Bunutin dengan ketinggian $200 \mathrm{~m}$ dpl, dengan kemiringan lereng berkisar antara 3\% sampai $45 \%$ dengan bentuk wilayah datar sarmpai berbukit.

Berdasarkan peta geologi pulau Bali bahan induk daerah penelitian terdiri dari bahan tuva vulknik. Secara administrasi daerah penelitian pada batas-batas wilayah sebagai berikut: (1) Sebelah utara dengan Desa Buahan, kecamatan Kintamani, (2) Sebelah barat dengan Desa Sekardadi, Kecamatan Susut, (3) Sebelah timur dengan Desa Abang Batudinding, Kecamatan Tembuku dan, (4) Sebelah Selatan, Kabupaten Ginyar. Penelitian dilakukan di Desa Pengotan, Desa Kubu dan Desa Bunutin. Daerah tersebut termasuk dalam wilayah Bangli Selatan, Kabupaten Bang

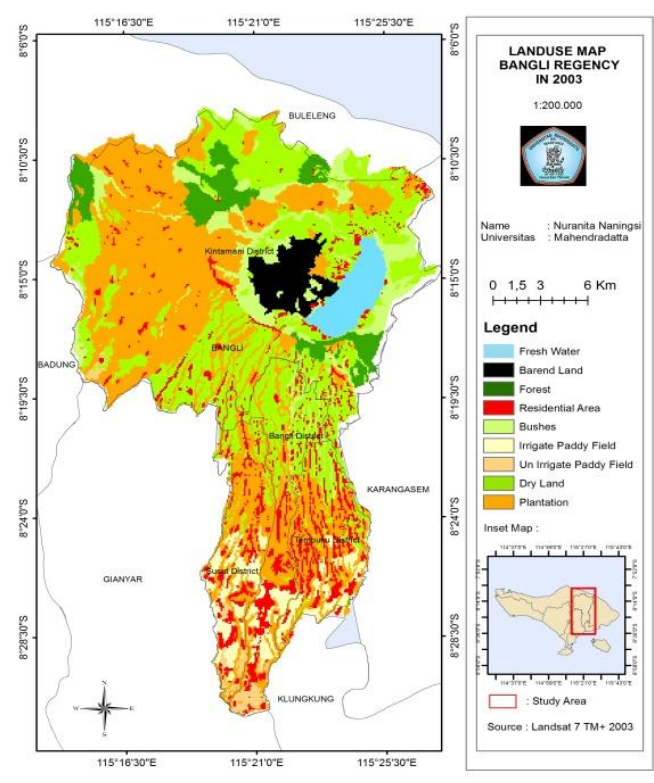

Gambar 1

Peta Penggunaan Lahan Kabupaten Bangli (2003) 
Berdasarkan klasifikasi iklim menurut Schmidt dan Ferguson (Winubroto, dkk, 1986) iklim tempat penelitian termasuk tipe iklim A (dengan iklim sangat basah) diambil dari ketinggian stasiun terdekat di Desa Pegotan, Kubu dan Bunutin Wilayah Bangli Selatan, Kabupaten Bangli.

\subsection{Bahan dan Alat}

Bahan-bahan yang digunakan dalam penelitian ini terdiri dari: contoh tanah yang diambil dari masing-masing horison pada setiap profil tanah dan zat-zat kimia untuk analisis contoh tanah di laboratorium: $\mathrm{H}_{2} \mathrm{SO}_{4}$, $\mathrm{HCL}, \mathrm{H}_{2} \mathrm{O}_{2}$ dan bahan-bahan lainnya.

Alat-alat yang digunakan dalam penellitian ini, terdiri dari: Peralatan yang dipergunakan untuk pekerjaan lapangan antara lain: sekop, kompas, ring sampel, pisau lapangan, meteran, abney level, buku warna tanah (Munsell Soil Color Cart), altimeter, pH meter dll. Untuk pekerjaan di Laboratorium menggunakan alat-alat seperti: $\mathrm{pH}$ elektroda, gelas ukur, tabung reaksi, oven, timbangan elektrik, pipet, dan peralatan laboratorium lainnya.

\subsection{Metode Penelitian}

Metode dalam penelitian ini adalah metode survai tanah dilapangan, dan ditunjang dengan analisis dilaboratorium, dan dilanjutkan dengan interpretasi data.

\subsubsection{Analisis Laboratorium}

Analisis sifat fisik tanah: Tekstur tanah, Bulk dencity, Permeabilitas tanah.

Sifat kimia tanah: Reaksi tanah $(\mathrm{pH})$ meliputi: $\mathrm{pH} \mathrm{H}_{2} \mathrm{O}, \mathrm{pH} \mathrm{KCL}$, dan $\mathrm{pH}$ Naf, Kapasitas Tukar Kation, C-Organik, Kejenuhan Basa dan P-retensi.

Analisis sifat mineral: Penetapan mineral liat dengan metode pengeringan dan indikator, penetapan persentasi Gelas vulkan dengan metode taburan dan bantuan mikroskop binokuler.

\subsubsection{Analisis Laboratorium}

Interpretasi data dilakukan setelah data di lapangan dari hasil analisis dilaboratorium didapatkan. Kegiatan ini dimaksudkan untuk mengetahui proses-proses perkembangan tanah pada lokasi penelitian, berdasarkan data yang diolah.
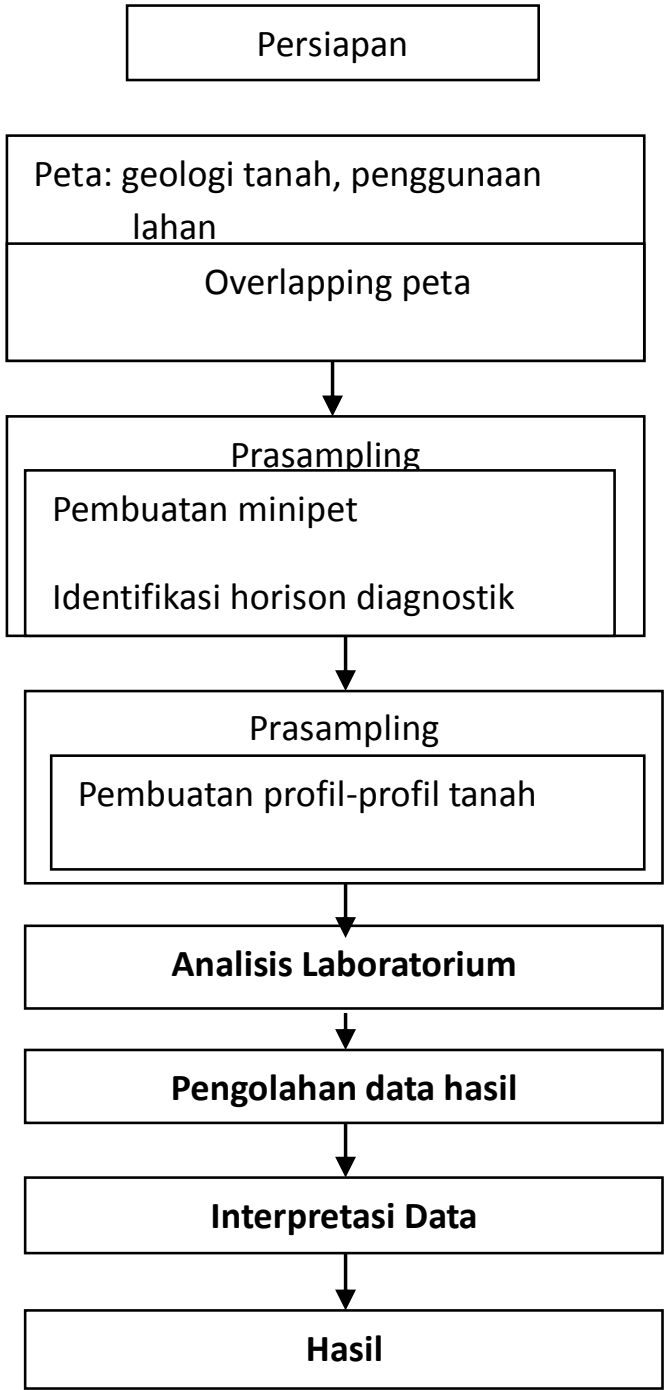

Gambar 2 Digram aliran penelitian 


\section{HASIL DAN PEMBAHASAN}

\subsection{Morfologi Tanah}

Tabel 1

Data Morfologi Tanah pada Pedon Pewakil di Desa Pengotan, Kubu dan Bunutin, Wilayah Bangli Selatan, Kab. Bangli.

\begin{tabular}{|c|c|c|c|c|c|c|c|c|}
\hline Pedon & $\begin{array}{l}\text { Simbol } \\
\text { Horison }\end{array}$ & $\begin{array}{c}\text { Kedalaman } \\
\text { (cm) }\end{array}$ & $\begin{array}{l}\text { Batas } \\
\text { Horsion }\end{array}$ & $\begin{array}{l}\text { Warna } \\
\text { Tanah }\end{array}$ & Tekstur & Struktur & Perakaran & Pori \\
\hline \multirow[t]{6}{*}{$\mathrm{N}-1$} & Ap & $0-22$ & $b, r$ & 10YR2/2 & - & - & ef, $\mathrm{mf}, \mathrm{fm}$ & am,ef,if \\
\hline & Bw1 & $22-61$ & $b, r$ & 10YR2/2 & SL & C & ef,mf,ff & af,em,if \\
\hline & Bw2 & $61-115$ & $b, r$ & 10YR3/3 & SL & C & ef, mf,ff & $a x, e x, f x$ \\
\hline & Bw3 & $115-153$ & $b, r$ & 10YR3/4 & SL & C & $c f, m x, f x$ & ax,ex,ix \\
\hline & $\mathrm{Bc}$ & $153-177$ & $b, r$ & 10YR2/2 & LS & C & $\mathrm{cf}, \mathrm{mx}, \mathrm{fx}$ & ax,ex,if \\
\hline & C & $>177$ & $b, r$ & 10YR3/4 & LS & C & $\mathrm{cf}, \mathrm{mx}, \mathrm{fx}$ & ax,ex,ix \\
\hline \multirow[t]{5}{*}{$\mathrm{N}-2$} & $A p$ & $0-33$ & $b, r$ & 10YR3/4 & $L$ & $\mathrm{Sb}$ & ef, $m x, f m$ & ax,ef,im \\
\hline & Bw1 & $33-78$ & $b, r$ & 10YR3/6 & $L$ & Sab & ef, $m x, f x$ & ax,ef,im \\
\hline & Bw2 & $78-120$ & $b, r$ & 10YR4/6 & LS & Sab & ef, $m x, f f$ & ax,ex,ix \\
\hline & $\mathrm{Bc}$ & $120-155$ & $b, r$ & 10YR4/6 & LS & Sab & $\mathrm{ex}, \mathrm{mx}, \mathrm{fx}$ & ax,ex,ix \\
\hline & $C$ & $>155$ & $b, r$ & 10YR4/6 & $\mathrm{SCL}$ & $\mathrm{Sb}$ & $e x, m x, f x$ & ax,ex,ix \\
\hline \multirow[t]{5}{*}{$N-3$} & Ap & $0-36$ & $b, r$ & 10YR3/3 & $\mathrm{CL}$ & $\mathrm{Sb}$ & ef,mf,fm & $a x, e x, i x$ \\
\hline & Bw1 & $36-67$ & $b, r$ & 10YR3/3 & $L$ & Scb & ef,mx,fx & ax,ex,ix \\
\hline & Bw2 & $67-100$ & $b, r$ & 10YR3/6 & $L$ & $A b$ & ex,mx,fx & ax,ex,ix \\
\hline & $\mathrm{Bc}$ & $100-132$ & $b, r$ & 10YR3/3 & $\mathrm{L}$ & Scb & $\mathrm{ex}, \mathrm{mx}, \mathrm{fx}$ & ax,ex,ix \\
\hline & C & $>132$ & $b, r$ & 10YR4/4 & $\mathrm{L}$ & Scb & $\mathrm{ex}, \mathrm{mx}, \mathrm{fx}$ & ax,ex,ix \\
\hline
\end{tabular}

\section{Keterangan}

Batas horsion: $b, r=b a u r$ dan rata, jr=jelas dan rata, b.a.r=berangsur dan rata; Tekstur: $\mathrm{CL}=$ lempung berliat, $\mathrm{SCL}=$ lempung liat berpasir, $\mathrm{C}=$ =liat, $\mathrm{L}=$ lempung $\mathrm{SL}$ =pasir berlempung, LS=lempung berpasir, $\mathrm{S}=$ pasir; Bentuk Struktur: $\mathrm{Sb}=$ gumpal membulat, $\mathrm{A} b=$ gumpal menyudut, $\mathrm{C}=$ granuler, $\mathrm{Sab}=$
Sab=gumpal agak membulat, $S c b=s u b$ angular blockly; ukuran perakaran: $f=h a l u s$, $\mathrm{m}=$ sedang, $\quad \mathrm{e}=\mathrm{kasar}$ (makro); jumlah perakaran: $x=t d k$ ada, $f=$ sedikit, $m=$ banyak; Pori: a=kasar(makro), e=sedang(meso), i=halus(mikro). 


\subsection{Sifat Fisik Tanah}

Tabel 2

Data Sifat fisika Tanah pada Pedon Pewakil Desa Pengotan, Kubu dan Bunutin, Wilayah Bangli Selatan, Kab. Bangli.

\begin{tabular}{|c|c|c|c|c|c|c|c|c|}
\hline \multirow{2}{*}{$\begin{array}{l}\text { Kode } \\
\text { profil }\end{array}$} & \multirow{2}{*}{ Horison } & \multicolumn{3}{|c|}{$\begin{array}{l}\text { Tekstur } \\
2003\end{array}$} & \multirow{2}{*}{$\begin{array}{l}\text { Kelas } \\
\text { Tekstur }\end{array}$} & \multirow{2}{*}{$\begin{array}{c}\text { Bulk } \\
\text { density } \\
\left(\mathrm{g} / \mathrm{cm}^{3}\right)\end{array}$} & \multirow{2}{*}{$\begin{array}{l}\text { Permeabilitas } \\
\text { (cm/jam) }\end{array}$} & \multirow{2}{*}{$\begin{array}{c}\text { Kelas } \\
\text { Permeabilitas }\end{array}$} \\
\hline & & $\begin{array}{l}\text { Pasir } \\
(\%)\end{array}$ & $\begin{array}{l}\text { Debu } \\
(\%)\end{array}$ & $\begin{array}{l}\text { Liat } \\
(\%)\end{array}$ & & & & \\
\hline \multirow{6}{*}{$\mathrm{N}-1$} & $A p$ & 79,299 & 19,484 & 1,218 & SL & 1,109 & 166,638 & SC \\
\hline & Bw1 & 63,865 & 34,797 & 1,338 & LS & 0,956 & 12,626 & C \\
\hline & Bw2 & 74,544 & 18,757 & 6,699 & LS & 0,803 & 75,985 & SC \\
\hline & Bw3 & 71,774 & 26,882 & 1,344 & LS & 0,830 & 7,737 & $A C$ \\
\hline & $\mathrm{Bc}$ & 70,04 & 25,685 & 4,281 & LS & 0,743 & 16,905 & $C$ \\
\hline & $C$ & 69,069 & 29,586 & 3,345 & LS & - & - & - \\
\hline \multirow{5}{*}{$\mathrm{N}-2$} & Ap & 51,097 & 29,638 & 19,265 & $\mathrm{~L}$ & 0,88 & 12,223 & $A C$ \\
\hline & Bw1 & 54,997 & 40,348 & 4,655 & LS & 0,92 & 6,313 & $A C$ \\
\hline & Bw2 & 58,462 & 33,846 & 7,692 & LS & 0,762 & 4,278 & $\mathrm{~S}$ \\
\hline & $\mathrm{Bc}$ & 55,485 & 43,079 & 1,436 & LS & 0,820 & 2,237 & $\mathrm{~S}$ \\
\hline & C & 48,317 & 50,207 & 1,477 & LB & - & - & - \\
\hline \multirow{5}{*}{$\mathrm{N}-3$} & Ap & 42,308 & 32,594 & 25,148 & $\mathrm{~L}$ & 0,836 & 18,127 & C \\
\hline & Bw1 & 47,818 & 31,626 & 20,557 & $\mathrm{~L}$ & 0,99 & 9,167 & $A C$ \\
\hline & Bw2 & 44,892 & 45,699 & 9,409 & $\mathrm{~L}$ & 1,222 & 2,848 & $\mathrm{~S}$ \\
\hline & $\mathrm{Bc}$ & 34,867 & 49,889 & 15,244 & $\mathrm{~L}$ & 0,97 & 3,868 & $\mathrm{~S}$ \\
\hline & $C$ & 37,569 & 47,170 & 15,261 & L & - & - & - \\
\hline
\end{tabular}

Keterangan:

Ld:Lempung berdebu

L:Lempung

LS:Lempung berpasir

SL:Pasir berlempung
SC:Sangat cepat

AC:Agak cepat

$S$ :Sedang

C :Cepat 
Berdasarkan hasil dilapangan pada Tabel 1, warna tanah pada profil $(\mathrm{N}-1)$ di Desa Pengotan, Profil (N-2) di Desa Kubu, dan profil $(\mathrm{N}-3)$ di Desa Bunutin menunjukkan warna yang gelap pada lapisan atas dan mengarah lebih terang kelapisan bawah. Warna tanah umumnya dipengaruhi oleh bahan organik tanah terutama lapisan top soil.

Struktur tanah pada profil ( $\mathrm{N}-1)$ adalah mulai dari struktur remah pada horison Ap sampai granuler pada horison c. Profil (N-2) horison Ap dan $C$ struktirnya gumpal membulat sedangkan horison Bw1, Bw2, dan Bc strtukturnya gumpal agak membulat. Profil $(\mathrm{N}-3)$ horison Ap strukturnya gumpal membulat sedangkan horison Bw1, Bc dan C strukturnya sub anggular blocky dan horison Bw2 strukturnya adalah gumpal menyudut. Hasil tersebut menunjukkan hubungan antara sttruktur dengan tekstur tanah, dimana tekstur tanah yang semakin halus maka struktur tanah semakin mantap, sebaliknya tekstur kasar struktur tanah akan berbutir tunggal.

Kondisi perakaran paada ketiga profil $(\mathrm{N}-$ 1), (N-2), dan (N-3) banyak terdapat pada horison bagian atas, baik akar halus, akar sedang dan akar kasar, dan semakin kearah bawah jumlah akar semakin sedikit bahkan sampai tidak ada. Pada ketiga profil akar menembus hingga horison bawah kecuali horison $\mathrm{C}$, hal ini mungkin disebabkan oleh jenis vegetasi pada daerah penelitian dan penanaman vegetasi yang kurang rapat.

Berdasarkan sifat morfologi tanah pada pada profil (N-1), (N-2), dan (N-3) mencirikan warna tanah yang gelap karena dipengaruhi oleh kandungan bahan organik. Struktur tanah gumpal membulat pada profil profil $(\mathrm{N}-2)$ dan $(\mathrm{N}-3)$, serta remah pada profil $(\mathrm{N}-1)$ dapat dipengaruhi oleh tekstur bahan induk, pergerakan akar tanaman, dan pengolahan tanah. Struktur tanah yang remah dan gumpal membulat memudahkan akar tanaman menembus tanah dan menyerap unsur hara, sehingga tanaman dapat tumbuh dengan baik.

Berdasarkan Tabel 2, kelas tekstur tanah pada profil $(\mathrm{N}-1)$ di Desa Pengotan, Profil (N-2) di Desa Kubu, dan profil (N-3) di Desa Bunutin menunjukkan pada profil $(\mathrm{N}-1)$ kelas teksturnya lebih kasar dibandingkan dengan profil $(\mathrm{N}-2)$ dan profil $(\mathrm{N}-3)$ kelas teksturnya sedang. Kandungan fraksi pasir yang juga lebih tinggi pada profil $(\mathrm{N}-1)$ dan kandungan lempung yang lebih tinggi pada profil (N-3) menunjukkan telah terjadi pengikisan atau alih tempat bahan yang lebih halus dari daerah atasan kedaerah bawahan yang lebih rendah.

Bulk density pada ketiga profil pewakil berkisar antara 0,743 sampai $1,222 \mathrm{~g} / \mathrm{cm}^{3}$. Rendahnya bulk density pada ketiga profil disebabkan oleh rendahnya kandungan liat, dan adanya bahan amorf dalam tanah.

Permeabilitas tanah pada ketiga profil adalah rendah sampai sangat cepaat, hal ini menunjukkan tanah cepat menyerap air dan meloloskan kelebihannya.

Berdasarkan hasil analisis sifat fisik tanah di laboratorium pada profil $(\mathrm{N}-1)$ di Desa Pengotan, Profil (N-2) di Desa Kubu, dan profil $(\mathrm{N}-3)$ di Desa Bunutin, menunjukkan tekstur tanah kasar sampai sedang karena dipengaruhi bahan induk. Bulk density tergolong rendah dipengaruhi oleh adanya bahan alofan dalam tanah dan rendahnya bahan organik tanah. Tekstur tanah yang kasar, dan struktur yang gumpal dan remah, memudahkan air untuk diserap oleh tanah dan meloloskan kelebihannya, sehingga permeabilitas tanahnya sangat cepat sehingga akan memudahkan dalam pengelolaan tanah dan pertumbuhan akar 


\subsection{Sifat kimia Tanah}

Tabel 3

Data Analisis sifat Kimia Tanah Pedon Pewakil di Desa Pengotan, Kubu dan Bunutin, Wilayah Bangli Selatan, Kab. Bangli.

\begin{tabular}{|c|c|c|c|c|c|c|c|c|c|c|}
\hline \multirow{2}{*}{$\begin{array}{l}\text { Kode } \\
\text { profil }\end{array}$} & \multirow{2}{*}{ Horison } & \multirow{2}{*}{$\begin{array}{c}\text { C.Organi } \\
\text { k(\%) }\end{array}$} & \multirow{2}{*}{ B.O(\%) } & \multirow{2}{*}{$\begin{array}{c}\text { KTK } \\
\text { (mll100gr } \\
\text { Tanah) }\end{array}$} & \multirow{2}{*}{ KB (\%) } & \multicolumn{2}{|c|}{ pH Naf } & \multirow{2}{*}{$\mathrm{pH} \mathrm{H} \mathrm{H}_{2} \mathrm{O}$} & \multirow{2}{*}{ pH KCL } & \multirow{2}{*}{$\begin{array}{c}\text { Retensi P } \\
(\%)\end{array}$} \\
\hline & & & & & & 2 Menit & 4 Menit & & & \\
\hline \multirow{6}{*}{$\mathrm{N}-1$} & Ap & 0,396 & 0,683 & 6,710 & 48,465 & 10,43 & 10,59 & 6,13 & 5,08 & 41,507 \\
\hline & Bw1 & 1,639 & 2,826 & 10,515 & 48,001 & 11,01 & 11,19 & 5,87 & 5,15 & 77,971 \\
\hline & Bw2 & 1,238 & 2,134 & 12,500 & 40,678 & 10,63 & 10,83 & 6,07 & 5,07 & 49,199 \\
\hline & Bw3 & 0,413 & 0,712 & 10,381 & 16,236 & 10,52 & 10,68 & 6,08 & 4,93 & 56,091 \\
\hline & $\mathrm{BC}$ & 1,318 & 2,272 & 19,842 & 27,273 & 10,41 & 10,64 & 5,73 & 4,84 & 84,383 \\
\hline & C & 0,428 & 0,738 & 15,385 & 34,285 & 10,25 & 10,48 & 5,94 & 4,85 & 76,208 \\
\hline \multirow{5}{*}{$\mathrm{N}-2$} & Ap & 1,751 & 3,019 & 20,450 & 52,746 & 10,55 & 10,70 & 5,67 & 4,80 & 85,184 \\
\hline & Bw1 & 0,446 & 0,769 & 22,910 & 63,999 & 10,47 & 10,67 & 5,79 & 4,70 & 81,978 \\
\hline & Bw2 & 0,423 & 0,729 & 28,230 & 64,616 & 9,90 & 10,07 & 6,07 & 4,48 & 70,998 \\
\hline & $\mathrm{BC}$ & 0,456 & 0,786 & 28,806 & 52,023 & 9,75 & 9,91 & 5,88 & 4,53 & 66,510 \\
\hline & C & 0,435 & 0,750 & 24,358 & 66,054 & 9,82 & 9,95 & 6,03 & 4,65 & 59,778 \\
\hline \multirow{5}{*}{$\mathrm{N}-3$} & $A p$ & 0,426 & 0,734 & 26,667 & 36,065 & 9,35 & 9,41 & 5,76 & 4,27 & 43,588 \\
\hline & Bw1 & 0,430 & 0,741 & 26,020 & 64,407 & 9,42 & 9,48 & 6,33 & 4,85 & 41,985 \\
\hline & Bw2 & 0,432 & 0,745 & 27,716 & 60,801 & 9,53 & 9,58 & 6,54 & 4,95 & 43,588 \\
\hline & $B C$ & 0,435 & 0,750 & 29,911 & 47,761 & 9,48 & 9,53 & 6,25 & 5,10 & 48,477 \\
\hline & C & 0,448 & 0,772 & 28,966 & 53,968 & 9,44 & 9,50 & 6,22 & - & 52,164 \\
\hline
\end{tabular}

Berdasarkan (tabel 3), ketiga profil menunjukkan reaksi tanah masam sampai agak masam, dengan nilai $\mathrm{pH}$ tanah dalam larutan $\mathrm{H}_{2} \mathrm{O}$ berkisar 5,67 sampai 6,54. Hal ini disebabkan oleh ion-ion yang terdapat dalam tanah bermuatan positif atau banyak mengandung ion $\mathrm{H}^{+}, \mathrm{Al}^{3+}$ dan $\mathrm{Fe}^{2+}$.

Kandungan bahan organik pada ketiga profil pewakil adalah sangat rendah sampai rendah, yakni berkisar $0,683 \%$ sampai $3,019 \%$. Rendahnya kandungan bahan organik pada ketiga profil pewakil diakibatkan oleh sumber dan dekomposisi bahan organik seperti sumber primer dan sumber sekunder yang menentukan kecepatan dekomposisi dan senyawa yang dihasilkan.

Kapasitas tukar kation ketiga profil tanah berkisar 6,710 sampai 29,911 me/100 g tanah. Profil (N-2) dan Profil (N-3) kapasitas kation tinggi, hal ini disebabkan oleh jenis dan kandungan mineral sekunder yang terlapuk, dan basa-basa yang dapat dipertukarkan, dengan melepaskan basa-basa tersebut dari koloid tanah, menyebabkan kejenuhan basa menjadi tinggi. Profil (N-1) kapasitas tukar kation rendah, hal ini disebabkan karena kebanyakan pertukaran kation, koloid organik, hidrogen, dan hidroksi-Al terikat kuat, sehingga sulit dipertukarkan, rendahnya kandungan liat, dan tipe mineral liatnya.

Berdasarkan hasil analisis kimia tanah pada profil (N-1) di Desa Pengotan, profil (N-2) di Desa Kubu, dan profil (N-3) di Desa Bunutin di Wilayah Bangli Selatan, menunjukkan reaksi tanah yang masam dipengaruhi oleh rendahnya basa-basa dalam tanah, bahan organik rendah disebabkan oleh reaksi masam pada tanah yang menyebabkan aktifitas organisme dalam menguraikan sisa-sisa tanaman dan hewan menjadi terhambat. Profil $(\mathrm{N}-2)$ dan profil $(\mathrm{N}-3)$ mempunyai kapasitas tukar kation tinggi dipengaruhi oleh jenis dan kandungan mineral sekunder yang terlapuk, dan basa-basa yang dipertukarkan, sedangkan profil ( $\mathrm{N}-1)$ kapasitas tukar kation rendah karena dipengaruhi oleh rendahnya jumlah liat dan jenis liat yang terdapat di daerah penelitian. 


\subsection{Perkembangan Horison Tanah}

Perkembangan tanah pada daerah penelitian sangat dipengaruhi oleh tipe bahan induk dan faktor iklim. Proses pedogenik utama pada ketiga profil pewakil terdiri dari proses dekomposisi dan alterasi. Abu vulkanis sebagai bahan induk tanah terdekomposisi menjadi mineral feldspar dan gelas vulkanis kemudian disintesis menjadi mineral liat alumino silikat amorf seperti alovan.

Proses-proses pembentukan tanah yang utama pada tanah didaerah penelitian adalah pelapukan mineral-mineral alumino silikat dan pembentukan mineral-mineral sekunder, terutama mineral alofan, serta transformasi mineral alofan menjadi mineral-mineral kristalin seperti haloisit. Terbentuknya mineral liat sebagai hasil pelapukan merupakan proses yang penting dalam pembentukan profil tanah, dimana jenis mineral liat yang terbentuk menunjukkan tingkat perkembangan tanah.

\subsubsection{Tingkat Pelapukan dan} Perkembangan Tanah

Tingkat pelapukan tanah dikaji berdasarkan data mineralogi tanah yaitu persentase mineral mudah lapuk dibandingkan dengan persentase mineral sukar lapuk pada masing-masing profil dapat disajikan pada Tabel 4. Sebagai berikut :

Tabel 4. Indeks pelapukan pada ketiga Profil Pengamatan diambil dari Rata-rata Horison B.

$\begin{array}{cccc}\text { Profil } & \text { MML* }^{*} & \text { MSL** } & \text { Rasio } \\ \text { N-1 } & 64,012 & 18,177 & 3,52 \\ \text { N-2 } & 76,929 & 20,98 & 3,6 \\ \text { N-3 } & 60,93 & 16,43 & 3,7 \\ * & =\text { Mineral mudah lapuk } & \\ * * & =\text { Mineral Sukar lapuk }\end{array}$

Dari parameter diatas, terlihat profil $(\mathrm{N}-1)$ memperlihatkan tingkat pelapukan yang lebih tinggi dari profil ( $\mathrm{N}-2)$ dan profil $(\mathrm{N}-3)$, hal ini ditunjukkan oleh rasio mineral mudah lapuk dengan mineral sukar lapuk akan semakin kecil nilainya dengan semakin tingginya tingkat pelapukan. Traveiner dan Eswaran (1972 dalam Hardjowigeno, 1993) mengatakan rasio indeks pelapukan akan semakin kecil, dengan meningkatnya pelapukan mineral tanah.

Mineral-mineral yang tergolong mudah lapuk adalah olivin, piroksin hornblende, biotit, plagioklas, ortoklas, gelas vulkan dan weathered mineral, sedangkan mineral yang tergolong sukar lapuk adalah muskovit, kuarsa, dan fragmen batuan (Darmawijaya, 1990).
Mega dkk., (1992) melakukan penelitian tentang sifat-sifat penduga tingkat perkembangan tanah. Untuk mengetahui tingkat perkembangan tanah pada ketiga profil pewakil, digunakan parameter sifat-sifat tersebut. Perkembangan tanah akan semakin meningkat dengan meningkatnya tebal solum, tebal horison $\mathrm{B}$ dan kandungan liat horison $\mathrm{B}$. Berdasarkan asumsi tersebut maka tingkat perkembangan tanah pada ketiga profil seperti pada Tabel 5. Sebagai berikut.

Tabel 5. Sifat-sifat Tanah Penduga Tingkat Perkembangan Tanah Pada Ketiga Profil Pengamatan.

$\begin{array}{lccc}\text { Profi } & \begin{array}{c}\text { Kedalaman } \\ \text { solum tanah } \\ \text { I }\end{array} & \begin{array}{c}\text { Tebal } \\ \text { Horison } \\ \text { B (cm) }\end{array} & \begin{array}{c}\text { Kandungan } \\ \text { liat Horison } \\ \text { B (\%) }\end{array} \\ \mathrm{N}-1 & 64,012 & 18,177 & 3,52 \\ \mathrm{~N}-2 & 76,929 & 20,98 & 3,6 \\ \mathrm{~N}-3 & 60,93 & 16,43 & 3,7\end{array}$

Berdasarkan pada paraeter-parameter diatas dalam menduga tingkat perkembangan tanah maka tingkat perkembangan tanah profil $(\mathrm{N}-3)$ lebih lanjut dibandingkan profil $(\mathrm{N}-1)$ dan profil (N-2). Hal ini dilihat dari kedalaman solum tanah $132 \mathrm{~cm}$ dengan tebal horison B $96 \mathrm{~cm}$ dan kandungan liat horison $B$ yang lebih tinggi. Peningkatan kandungan liat dihorison $B$ sangat dipengaruhi oleh proses iluviasi dan eluviasi yang intensif karena terjadi pencucian liat dihorison $A$ dan terakumulasi dihorison $B$, dapat dilihat pada horison $B$ yang terjadi peningkatan jumlah liat. Tingkat perkembangan tanah di DesaPengotan, Desa Kubu, dan Desa Bunutin, diwilayah Bangli Selatan berada pada tingkat virile. Proses perkembangan yang terjadi adalah pelapukan yang mengalami proses penghanyutan bahan tanah pada lereng atas, lereng bawah, lereng tengah mengalami proses eluviasi dan lereng bawah mengalami proses deposisi.

\section{KESIMPULAN DAN SARAN}

\subsection{Kesimpulan}

Berdasarkan hasil penelitian di Desa Pengotan, Kubu dan Bunutin, di wilayah Bangli Selatan, Kabupaten Bangli maka di peroleh beberapa kesimpulan sebagai berikut:

1. Proses perkembangan tanah yang terjadi di Desa Pengotan, Desa Kubu dan Bunutin di wilayah Bangli Selatan adalah proses penghanyutan bahan tanah ditunjukkan oleh profil (N-1) sehingga membentuk solum dangkal, proses eluviasi ditunjukkan oleh profil (N-2) sehingga membentuk 
solum yang lebih dalam, dan proses deposisi ditunjukkan oleh profil (N-3) sehingga membentuk solum yang sangat dalam. Tingkat perkembangan tanah pada ketiga profil berada pada tingkat virile.

2. Karaktristik tanah berdasarkan ketinggian tempat dapat diamati: reaksi tanah agak masam, kapasitas tukar kation rendah sampai tinggi, kejenuhan basa sedang sampai tinggi, bahan organik sangat rendah sampai rendah, terkstur pasir berlempung sampai lempung. Jenis mineral yang terdapat pada ketiga profil didominasi oleh mineral haloisit.

3. Analisis tingkat perkembangan tanah secara morfologik menunjukkan tanah semakin berkembang menurut urutan daerah atas profil (N-1) Desa Pengotan, daerah tengah profil (N-2) desa Kubu, sampai daerah bawah profil (N-3) Desa Bunutin dari atas sampai kebawah.

4. Tingkat pelapukan ketiga pedon tergolong rendah yang dicirikan oleh kandungan mineral mudah lapuk seperti piroksin, olivin, horblende, biotit, plagioklas,ortoklas, gelas vulkanik dan lapukan mineral lebih rendah dibanding mineral sukar lapuk seperti muscovite, kuarsa dan fragme batuan.

\subsection{Saran}

1. Pada daerah penelitian ini kandungan bahan organiknya tergolong rendah dan untuk mengoptimalkan potensi lahan pada daerah yang akan dipertaniankan maka perlu diberikan penambahan bahan organik.

2. Pada profil ( $\mathrm{N}-1)$ yang berada pada lereng atas perlu mendapatkan sedikit pengelolaan tanah dengan alternatif pembuatan terasering, mengingat tanah tersebut memiliki ketinggian tempat yang cukup tinggi sehingga rawan terhadap erosi.

\section{DAFTAR PUSTAKA}

Arsad, S. 1989. "Soil and Water conservation". IPB Press, Bogor.

Badan Pusat Statistik, Kabupaten Bangli 2001. Bangli dalam angka tidak dipublikasikan.

Darmawijaya, 1997. Klasifikasi Tanah Dasar Teori Bagi Peneliti Tanah dan Pelaksanaan Pertanian di Indonesia. Edisi kedua. Gadjah Mada university Pres Yogyakarta.

Djaenudin, D..1979. Peranan Faktor Lereng Dalam Evaluasi Lahan di Daerah Perbukitan sebagai studi kasus di Das Citarum atas antara Cimahi-Batutajar. Tesis MS. Departemen IImu Tanah
Fakultas Pertanian IPB Bogor. Tidak dipublikasikan.

Hardjowigeno, S. 1993. "Soil Klasifikasi and Pedogenesis". Akademika Pressindo. Jakarta.

Mega, I.M. Penuntun Praktikum Morfologi dan Klasifikasi Tanah. Jurusan Tanah Fakultas Pertanian Universitas Udayana. Denpasar.

Nuril Hidayatati, Chalid Talib. 1994. Tanah Kritis Pencegahan dan Pemulihannya. Penerbit Nusa Indah. Bogor.

Wisnubroto, S., S. L. Aminah S. Dan M. Nitisapto, 1986. Asas-asas Meteorologi Pertanian. Laboratorium Meteorologi Pertanian Departemen IImu Tanah Fakultas Pertanian Universitas Gadjah Mada. 